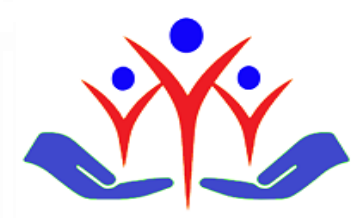

Family Practice and Palliative Care

doi https://doi.org/10.22391/fppc.747615

Research Article

\title{
The relationship between sleep and metabolic factors in diabetes mellitus
}

\author{
Diabetes mellitusta uyku ile metabolik faktörler arasındaki ilişki
}

\author{
iD Zeynep Altin ${ }^{\mathbf{a}}$, iD Burcu Bayrak \\ a Department of Internal Medicine, Tepecik Training and Research Hospital, Health Sciences University, Izmir, Turkey \\ Department of Diabetes Education Policlinic, Tepecik Training and Research Hospital, Health Sciences University, Izmir, \\ Turkey
}

\begin{abstract}
Introduction: This study was conducted to determine the relationship between sleep status and sociodemographic features, body mass index (BMI), blood pressure (BP), additional diseases, duration of diabetes mellitus diagnosis, received therapies, and laboratory values in patients with diabetes mellitus.

Methods: The study was carried out with 200 adult diabetic patients applying to the Internal Medicine Department of Tepecik Training and Research Hospital with normal cognitive function and without any known psychiatric disorder. The research was conducted between July 10 and August 31, 2019. Sociodemographic data of patients were recorded, and the Pittsburgh Sleep Quality Index (PSQI) was applied. Those with a total score of 5 or above were considered poor, while those less than 5 were deemed good.

Results: Of the 200 patients, $64 \%(\mathrm{n}=128)$ were female, and $36 \%(\mathrm{n}=72)$ were male. The mean total PDQI score was 10.44 . Sleep quality was good in $7.5 \%$, while poor in $92.5 \%$. In both genders, the mean total score was greater than five. However, there was a statistically significant difference according to gender. Namely, $3.9 \%$ of women had good sleep quality, which was $13.9 \%$ among men ( $\mathrm{p}=0.010$ ). Higher educational status was related to higher sleep quality $(\mathrm{p}=0.007)$. Sleep quality was further impaired in patients with additional hypertension, hyperlipidemia, or coronary artery disease $(\mathrm{p}=0.010)$. The sleep quality of those living with their spouses was lower than that of other participants $(\mathrm{p}=0.033)$. There was no statistically significant difference between mean PUKI total scores and diabetes type, BMI, BP, lipid values, fasting \& postprandial blood glucose, creatinine, or ALT values ( $p>0.05)$.
\end{abstract}

Conclusion: Sleep quality is poor in diabetics. Clinicians should handle patients' sleep status during diabetes mellitus follow-up. Interventions to increase sleep quality in diabetics will no doubt improve the quality of life.

Keywords: Diabetes mellitus, sleep, blood glucose, coronary artery disease, hyperlipidemias

$\ddot{O} \mathbf{z}$

Giriș: Bu çalıșmada, Diabetes Mellitus tanısı ile takip edilen hastalarda, sosyodemografik özellikler, kan basıncı, beden kitle indeksi, ek hastalıklar, diyabet süresi, medikal tedavi ve biyokimyasal parametreler ile uyku durumu arasındaki ilişkinin araştırılması amaçlanmıștır.

Yöntem: Bu prospektif ve kesitsel çalışma 1 Haziran- 31 Ağustos 2019 tarihleri arasında İç hastalıkları polikliniğine başvuran 200 Diabetes Mellitus tanılı hasta ile yürütülmüștür. Katılımcıların uyku durumu, Pittsburgh Uyku Kalitesi İndeksi (PUKİ) ile değerlendirilmiștir. PUKİ toplam puanı 5 ve üzeri uyku kalitesi kötü, toplam puan 5'in altı ise iyi uyku kalitesi olarak sınıflandırılmıştır.

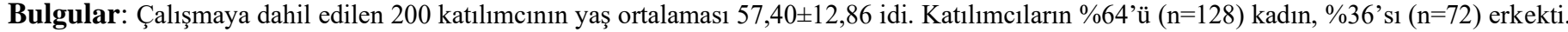
Hastaların PUKİ toplam puan ortalaması 10,44 idi. Katılımcıların \%7,5'inde uyku kalitesi iyi, \%92,5'inde ise kötü saptandı. Erkeklerde (p=0,010), eğitim düzeyi yüksek olanlarda $(\mathrm{p}=0,012)$ uyku kalitesi daha yüksek saptandı. Diabetes Mellitusa, hipertansiyon, hiperlipidemi veya koroner arter hastalığının eşlik ettiği durumlarda da $(\mathrm{p}=0,028)$ uyku kalitesi daha düşük saptandı. Diabetes Mellitus tipi, vücut kitle indeksi (VKI), kan basıncı, lipit değerleri, açlık ve tokluk kan şekeri, kreatinin ve ALT değerleri ile PUKİ toplam puan ortalamaları arasında istatistiksel olarak anlamlı fark bir bulunmadi $(\mathrm{p}>0,05)$.

Sonuç: Diabetes Mellitus tanısı ile takip edilen hastaların uyku kalitesi kötü saptanmıştır. Bozulmuş uyku kalitesi birçok hastalığın etyolojisi ve seyrinde rol alabilir. Klinisyenler, Diabetes Mellitus takibinde hastaların uyku durumları ile de ilgilenmelidir. Diabetes Mellitus nedeni ile takip edilen hastaların uyku kalitesinin artırılması için müdahalelerde bulunulması, hastaların yaşam kalitesini artırabilir.

Anahtar kelimeler: Diabetes mellitus, uyku, kan şekeri, koroner arter hastalığı, hiperlipidemi

\begin{tabular}{|c|c|c|c|c|}
\hline Received & Accepted & Published Online & Corresponding Author & E-mail \\
\hline June 3, 2020 & November 3, 2020 & December 18, 2020 & Zeynep ALTIN, MD & zeynpdr@ hotmail.com \\
\hline Correspondence & $\begin{array}{l}\text { Dr. Zeynep ALTIN, Health Sciences University, Tepecik Training and Research Hospital, Department of } \\
\text { Internal Medicine, 35180, İzmir-Turkey }\end{array}$ \\
\hline
\end{tabular}




\section{Introduction}

Diabetes mellitus is a chronic metabolic disease with high blood sugar, in which essential nutrients cannot be used effectively due to partial or complete deficiency of the insulin hormone or defects in its mechanism of action [1]. Its pathogenesis is only partially understood. Diabetes mellitus can cause complications in many systems in the human body. Therefore, it requires constant follow-up, care, and treatment. It is estimated that diabetes mellitus affects 425 million people worldwide [2]. According to the analysis of current data, the prevalence of type 2 diabetes mellitus diagnosed in adults in the United States is approaching 10 percent [3, 4]. According to the Heart Disease and Risk Factors in Turkish Adults (TEKHARF) research, the number of diabetes mellitus cases in Turkey will double in about 10 years [5]. Given the marked increase in childhood obesity, the prevalence of diabetes mellitus will continue to increase significantly [6]. Due to the rise in the total number of cases and its complications, diabetes mellitus is considered a serious health problem, and $10 \%$ of the health expenditures in the world are spent on the treatment of diabetes mellitus and its complications [7].

Sleep, which constitutes approximately one-third of the life span of a healthy adult, is important for the quality and maintenance of cognitive functions as well as physical and psychological well-being [8]. Therefore, healthy sleep is essential for quality of life. Seven to eight hours of sleep per day is considered normal in an adult. However, the need for sleep may differ individually. Insufficient and poor-quality sleep causes an increase in morbidity and mortality. The role of diabetes mellitus as one of the diseases causing this increase in morbidity and mortality has been discussed in the literature [9]. Metabolic syndrome components, such as hyperinsulinemia, central obesity, and glucose intolerance, are seen in the obstructive sleep apnea mentioned among sleep disorders and play a role in the mechanism of diabetes mellitus formation [10]. After defining the relationship between diabetes mellitus and sleep disorders, the American Diabetes Association recommended a "comprehensive evaluation of sleep pattern and duration" in 2017 [11, 12]. Unfortunately, quality sleep is not sufficiently examined during the follow-up of clinicians. Therefore, to open a new area of sleep regulation in the management of diabetes mellitus and to find the response of this intervention in clinical practice, further research should be emphasized, and related factors should be evaluated. Based on this, it is thought that, if present, the treatment of sleep disorders and the revision of sleep duration according to individual differences may positively affect the metabolic variables of patients.

In this study, we aimed to investigate sleep quality in patients diagnosed with diabetes mellitus. Furthermore, the relationships between body mass index, arterial blood pressure, blood glucose, creatinine, alanine aminotransferase (ALT), lipid parameters, and proteinuria which are important in the development of coronary artery disease, retinopathy, and nephropathy, which, in turn, are crucial in the course of diabetes were investigated in patients with good and poor subjective sleep quality.

\section{Methods}

\section{Study design and population}

The study was designed prospectively and cross-sectionally. After determining the minimum difference (effect size) that can be considered clinically significant between the two group means or proportions, to achieve an $80 \%$ (1-Beta) power in analyzing the study hypothesis given a type-1 error probability of $5 \%$ (Alpha), the appropriate sample size to be used in the study was calculated as 200 with G-Power. As a result of sample size calculation, the research was planned to be conducted with 200 participants having diabetes mellitus. All individuals admitted to the internal medicine outpatient clinic of Health Sciences University Tepecik Training and Research Hospital (Turkey) between July 10 and August 31, 2019, who were previously diagnosed with diabetes mellitus, being followed up on an outpatient basis, over 18 years of age, literate, able to adhere to assessments, having no known sleep disorder, who accepted to participate in the study, who had no known psychiatric disorders or drug use history that could adversely affect sleep quality, were included in the study. Before being included, a mini-mental test was applied to all volunteers who agreed to participate in the study. Participants with a mini-mental test score below 24 points were excluded from the study. No new participants were recruited once the number of participants meeting the study criteria and having a mini-mental test score of 24 and above reached 200 (female: 128, male: 72). A data collection form prepared by searching the literature data, and the "Pittsburgh Sleep Quality Index (PSQI)" was administered to the participants using a face-to-face interview method.

\section{Ethical approval}

The study was approved by the Ethics Committee of Health Sciences University Tepecik Training and Research Hospital (Decision Date: July 10, 2019; Decision No: 2019/11-18) and carried out under the principles of the Helsinki Declaration. All participants signed an informed consent form for inclusion in the study.

\section{Data collection}

The sociodemographic characteristics of the participants (age, gender, marital status, educational status, employment status, profession, income level, residency partners) were obtained with a data collection form, which was prepared by reviewing literature data, using face-to-face interview technique with the participants. Information on the participants' current co-morbid diseases and diabetes mellitus, type of the disease, the time elapsed since the diagnosis of diabetes, and the treatment type (oral/insulin) were obtained from hospital records and patient anamnesis. The height and weight of the participants were measured using standard measurement tools during the outpatient clinic visit, and the body mass index (BMI) was calculated, dividing the weight by the square of the height measurement (BMI $=\mathrm{kg} / \mathrm{m} 2$ ). Those with a body mass index below 18.49 were categorized as low, 18.50-24.99 as normal, 25-29.99 as slightly overweight, and values above 30 as obese. Blood pressure was measured with a manual sphygmomanometer in the same position while the individual sitting for at least 10 minutes. Fasting blood glucose and lipid values were obtained between 08:00-12:00 am, after 12 hours of fasting, and postprandial blood glucose was taken 2 hours after the first bite of the meal. Fasting and postprandial blood glucose levels were evaluated from venous plasma samples. Participants were categorized by age as 65 or older (elderly) and under 65 (non-elderly). Among the biochemical parameters of the participants, creatinine, ALT, HbA1c, and spot urinary protein and creatinine (proteinuria) levels were obtained from the data recorded during routine polyclinic follow-ups. 
The Mini-Mental Test (MMT) was developed in 1975 by Folstein et al. It was developed for cognitive assessment purposes and was standardized by Molly and Standish in 1997. [13,14]. Its Turkish validity and reliability were determined in 2002 by Gungen et al. The test provides a score between $0-30$. If the score is above 24 , it is accepted that there is no cognitive impairment. The sensitivity and specificity values were reported as $0.91 \%$ and $0.95 \%$, respectively [15].

\section{Evaluation of sleep status}

The Pittsburgh Sleep Quality Index (PSQI) scale was used to evaluate the sleep quality of the participants. The PSQI scale was developed in 1989 by Buyse et al. Its validity and reliability study in Turkey was developed by Agargun et al. The Cronbach's alpha internal consistency coefficient of the scale is $0.80[16,17]$. The PSQI scale is designed to evaluate sleep quality in the last 4 weeks. The scale consists of 7 sections that test subjective sleep quality, sleep latency, sleep duration, habitual sleep efficiency, sleep disorder, use of sleeping pills, and daytime dysfunction. Each section is scored between 0-3. While some parts are evaluated with a single question, some parts are calculated by formulating the scores of several items. As a result, the sum of the scores calculated for 7 sections is between $0-21$. A total score of 5 and above indicates poor sleep quality, and a score below 5 indicates good sleep quality.

\section{Statistical analysis}

The IBM Statistical Package for the Social Sciences (SPSS) 25.0(SPSS Inc., Chicago, IL, USA) was used to analyze the data. The Shapiro-Wilk test was used to determine whether the data followed a normal distribution. Descriptive statistics of the data are reported as mean and standard deviation [mean $\pm \mathrm{std}$ ] for variables with normal distribution in continuous data, and frequency, and percentage [n (\%)] for categorical variables. A Chi-square test was used in the analysis of categorical data. Results were accepted at a $95 \%$ confidence interval, and the statistical significance level was set to $\mathrm{p}<0.05$.

\section{Results}

The mean PSQI scale score of diabetic patients participating in the study was determined as $10.44 \pm 3.84$. Average scores obtained from the PSQI components of the diabetes patients participating in the study are shown in Table 1.

Table 1. Mean Scores of Participants for PSQI Components $(n=200)$

\begin{tabular}{lccc}
\hline & Min & Max & Mean \pm SD \\
\hline $\begin{array}{l}\text { Sleep Component 1 } \\
\text { Subjective Sleep Quality } \\
\text { Sleep Component 2 }\end{array}$ & 0 & 3 & $2 \pm 0.85$ \\
$\begin{array}{l}\text { Sleep Latency } \\
\text { Sleep Component 3 }\end{array}$ & 0 & 3 & $1.02 \pm 0.78$ \\
$\begin{array}{l}\text { Sleep Duration } \\
\text { Sleep Component 4 }\end{array}$ & 0 & 3 & $0.89 \pm 0.92$ \\
$\begin{array}{l}\text { Habitual Sleep Activity } \\
\text { Sleep Component 5 }\end{array}$ & 0 & 3 & $0.84 \pm 1.04$ \\
$\begin{array}{l}\text { Sleep Disorder } \\
\text { Sleep Component 6 }\end{array}$ & 0 & 3 & $1.94 \pm 0.79$ \\
$\begin{array}{l}\text { Sleeping Pills Usage } \\
\text { Sleep Component 7 }\end{array}$ & 0 & 3 & $0.80 \pm 1.87$ \\
$\begin{array}{l}\text { Daytime Dysfunction } \\
\text { PSQI }\end{array}$ & 0 & 21 & $2.19 \pm 0.95$ \\
Sleep Quality Total Score & 0 & & $10.44 \pm 3.84$ \\
\hline
\end{tabular}

Mean \pm SD: Mean \pm standard deviation PSQI: Pittsburgh Sleep Quality Index

Participants in the study were classified as having good sleep quality (PSQI $<5)$ and poor sleep quality (PSQI $\geq 5$ ), and sleep qualities were examined according to sociodemographic characteristics (Table 2). Sleep quality was good in $7.5 \%(\mathrm{n}=15)$ of the study participants and poor in $92.5 \%$ $(\mathrm{n}=185)$. Among the sociodemographic characteristics, gender and education levels were the factors affecting sleep quality. Sleep quality of males compared to females $(\mathrm{p}=0.010)$, and individuals with an education level of secondary school and above compared to individuals with primary school or below education were found to have better sleep quality $(\mathrm{p}=0.012)$.

Of the participants, $73.5 \%(n=147)$ stated that they had at least one additional disease besides diabetes mellitus. The sleep quality of patients with co-morbidities was worse than that of the patients with diabetes mellitus alone $(\mathrm{p}=0.028)$ (Table 3$)$.

There was no statistically significant difference between sleep quality and BMI, systolic and diastolic blood pressure, laboratory values in individuals diagnosed with diabetes ( $p>0.05$ ). In 143 of the individuals, proteinuria <300 mg/day was detected. Proteinuria was 300-1000 mg/day in 1 person, and $>1000 \mathrm{mg} / \mathrm{day}$ in 1 person. Therefore, the relationship between proteinuria and sleep quality was not included in the analysis (Table 4). 
Table 2. Relationship between sociodemographic characteristics of participants and sleep quality

\begin{tabular}{|c|c|c|c|c|c|c|c|}
\hline & \multicolumn{2}{|c|}{ Poor Sleep Quality } & \multicolumn{2}{|c|}{ Good Sleep Quality } & \multicolumn{2}{|c|}{ Total } & \multirow[b]{3}{*}{$\mathbf{p}$} \\
\hline \multirow{2}{*}{$\begin{array}{c}\text { Sociodemographic } \\
\text { Features }\end{array}$} & & & & & & & \\
\hline & $\mathbf{N}$ & $\%$ & $\mathbf{N}$ & $\%$ & $\mathbf{N}$ & $\%$ & \\
\hline \multicolumn{8}{|l|}{ Age } \\
\hline Under 65 & 128 & 93.4 & 9 & 6.6 & 137 & 100.0 & 0.564 \\
\hline 65 and over & 57 & 90.5 & 6 & 9.5 & 63 & 100.0 & \\
\hline \multicolumn{8}{|l|}{ Gender } \\
\hline Male & 123 & 96.1 & 5 & 3.9 & 128 & 100.0 & $0.010^{*}$ \\
\hline Female & 62 & 86.1 & 10 & 13.9 & 72 & 100.0 & \\
\hline \multicolumn{8}{|l|}{ Marital Status } \\
\hline Married & 139 & 93.9 & 9 & 6.1 & 148 & 100.0 & 0.224 \\
\hline Single & 46 & 88.5 & 6 & 11.5 & 52 & 100.0 & \\
\hline \multicolumn{8}{|l|}{ Education Status } \\
\hline Literate/Primary School & 169 & 94.4 & 10 & 5.6 & 179 & 100.0 & $0.012^{*}$ \\
\hline Secondary school and above & 16 & 76.2 & 5 & 23.8 & 21 & 100.0 & \\
\hline \multicolumn{8}{|l|}{ Working Status } \\
\hline Yes & 21 & 91.3 & 2 & 8.7 & 23 & 100.0 & 0.685 \\
\hline No & 164 & 92.7 & 13 & 7.3 & 177 & 100.0 & \\
\hline \multicolumn{8}{|l|}{ Income Status } \\
\hline Income $<$ Expense & 41 & 93.2 & 3 & 6.8 & 44 & 100.0 & 0.558 \\
\hline Income $=$ Expense & 140 & 92.7 & 11 & 7.3 & 151 & 100.0 & \\
\hline Income $>$ Expense & 4 & 80.0 & 1 & 20.0 & 5 & 100.0 & \\
\hline \multicolumn{8}{|l|}{ Lives With } \\
\hline Alone & 18 & 90.0 & 2 & 10.0 & 20 & 100.0 & 0.824 \\
\hline Spouse & 48 & 90.6 & 5 & 9.4 & 53 & 100.0 & \\
\hline Spouse and children & 97 & 94.2 & 6 & 5.8 & 103 & 100.0 & \\
\hline Children and other & 22 & 91.7 & 2 & 8.3 & 24 & 100.0 & \\
\hline
\end{tabular}

$\mathrm{N}$ : frequency, \%: percentage. Row percentages are presented. $* \mathrm{p}<0.05$ was considered statistically significant.

Table 3. Relationship between clinical characteristics of participants and sleep quality

\begin{tabular}{|c|c|c|c|c|c|c|c|}
\hline \multirow{2}{*}{ Clinical Features } & \multicolumn{2}{|c|}{ Poor Sleep Quality } & \multicolumn{2}{|c|}{ Good Sleep Quality } & \multicolumn{2}{|c|}{ Total } & \multirow[b]{2}{*}{$\mathbf{p}$} \\
\hline & $\mathbf{N}$ & $\%$ & $\mathbf{N}$ & $\%$ & $\mathbf{N}$ & $\%$ & \\
\hline \multicolumn{8}{|l|}{ Additional Illness } \\
\hline Yes & 140 & 95.2 & 7 & 4.8 & 147 & 100.0 & $0.028^{*}$ \\
\hline No & 45 & 84.9 & 8 & 15.1 & 53 & 100.0 & \\
\hline \multicolumn{8}{|l|}{ Diabetes Type } \\
\hline Type I & 4 & 66.7 & 2 & 33.3 & 6 & 100.0 & 0.066 \\
\hline Type II & 181 & 93.2 & 13 & 6.7 & 194 & 100.0 & \\
\hline \multicolumn{8}{|l|}{ Diagnosis Duration } \\
\hline$\leq 5$ years & 95 & 93.1 & 7 & 6.9 & 102 & 100.0 & 0.727 \\
\hline$>5$ years & 90 & 91.8 & 8 & 8.2 & 98 & 100.0 & \\
\hline \multicolumn{8}{|l|}{ Treatment } \\
\hline Insulin & 38 & 95.0 & 2 & 5.0 & 40 & 100.0 & 0.792 \\
\hline OAD & 88 & 91.7 & 8 & 8.3 & 96 & 100.0 & \\
\hline Insulin + OAD & 59 & 92.2 & 5 & 7.8 & 64 & 100.0 & \\
\hline
\end{tabular}

$\mathrm{N}$ : frequency, \%: percentage. Row percentages are presented. ${ }^{*} \mathrm{p}<0.05$ was considered statistically significant. OAD: Oral anti-diabetics 
Table 4. Relationship between participants' metabolic parameters and sleep quality

\begin{tabular}{|c|c|c|c|c|c|c|c|}
\hline & \multicolumn{2}{|c|}{ Poor Sleep Quality } & \multicolumn{2}{|c|}{ Good Sleep Quality } & \multicolumn{2}{|l|}{ Total } & \multirow[b]{2}{*}{$\mathbf{p}$} \\
\hline Metabolic Parameters & $\mathbf{N}$ & $\%$ & $\mathbf{N}$ & $\%$ & $\mathbf{N}$ & $\%$ & \\
\hline \multicolumn{8}{|l|}{ Body Mass Index } \\
\hline Low & 0 & 0.0 & 0 & 0.0 & 0 & 0.0 & 0.388 \\
\hline Normal & 15 & 100.0 & 0 & 0.0 & 15 & 100.0 & \\
\hline Overweight & 73 & 90.1 & 8 & 9.9 & 81 & 100.0 & \\
\hline Obese & 94 & 93.1 & 7 & 6.9 & 101 & 100.0 & \\
\hline \multicolumn{8}{|l|}{ Systolic Blood Pressure } \\
\hline$\leq 135$ & 127 & 90.1 & 14 & 9.9 & 141 & 100.0 & 0.073 \\
\hline$>135$ & 58 & 98.3 & 1 & 1.7 & 59 & 100.0 & \\
\hline \multicolumn{8}{|l|}{ Diastolic Blood Pressure } \\
\hline$\leq 85$ & 139 & 90.8 & 14 & 9.2 & 153 & 100.0 & 0.201 \\
\hline$>85$ & 46 & 97.9 & 1 & 2.1 & 47 & 100.0 & \\
\hline \multicolumn{8}{|l|}{ Satiety Blood Glucose } \\
\hline$\leq 160$ & 31 & 91.2 & 3 & 8.8 & 34 & 100.0 & 0.703 \\
\hline$>160$ & 151 & 93.8 & 10 & 6.2 & 161 & 100.0 & \\
\hline \multicolumn{8}{|l|}{ Fasting Blood Glucose } \\
\hline $70-105$ & 31 & 88.6 & 4 & 11.4 & 35 & 100.0 & 0.577 \\
\hline $105-126$ & 31 & 91.2 & 3 & 8.8 & 34 & 100.0 & \\
\hline$>126$ & 119 & 93.7 & 8 & 6.3 & 127 & 100.0 & \\
\hline \multicolumn{8}{|l|}{ Creatine } \\
\hline$\leq 1.4$ & 165 & 92.7 & 13 & 7.3 & 178 & 100.0 & 0.643 \\
\hline$>1.4$ & 17 & 89.5 & 2 & 10.5 & 19 & 100.0 & \\
\hline \multicolumn{8}{|l|}{ ALT } \\
\hline$\leq 50$ & 169 & 93.4 & 12 & 6.6 & 131 & 100.0 & 0.141 \\
\hline$>50$ & 15 & 83.3 & 3 & 16.7 & 18 & 100.0 & \\
\hline \multicolumn{8}{|l|}{ LDL } \\
\hline$\leq 100$ & 57 & 89.1 & 7 & 10.9 & 64 & 100.0 & 0.254 \\
\hline$>100$ & 126 & 94.0 & 8 & 6.0 & 134 & 100.0 & \\
\hline \multicolumn{8}{|l|}{ Triglyceride } \\
\hline$\leq 150$ & 77 & 90.6 & 8 & 9.4 & 85 & 100.0 & 0.394 \\
\hline$>150$ & 106 & 93.8 & 7 & 6.2 & 113 & 100.0 & \\
\hline \multicolumn{8}{|l|}{ HbA1c } \\
\hline$<6.5$ & 53 & 96.3 & 2 & 3.7 & 55 & 100.0 & 0.487 \\
\hline $6.6-7$ & 25 & 86.4 & 4 & 13.6 & 29 & 100.0 & \\
\hline $7.1-7.8$ & 31 & 91.4 & 3 & 8.6 & 34 & 100.0 & \\
\hline$>7.9$ & 76 & 92.7 & 6 & 7.3 & 82 & 100.0 & \\
\hline
\end{tabular}

N: frequency, \%: percentage. Row percentages are presented. *p<0.05 was considered statistically significant. LDL: low-density lipoprotein

\section{Discussion}

Poor sleep quality may be the first symptom of many diseases [18]. Chronic insufficient sleep, obstructive sleep apnea syndrome (OSAS) and insomnia are quite common in patients with type 2 diabetes mellitus. Prospective studies suggest that these conditions may increase the risk of diabetes mellitus or worsen prognosis in the presence of diabetes mellitus [19]. Interventional studies addressing sleep abnormalities in individuals with diabetes mellitus are rare. Therefore, details on how strategies to improve sleep may prevent type 2 diabetes mellitus or the clinical consequences in people with overt diabetes are not well understood. Although it depends on many different conditions, sleep disorders are seen at a rate of $5-71 \%$ [20]. Akova et al. reported the incidence of poor sleep quality as 50.4\% in their study on individuals over 20 years of age [21]. In a meta-analysis conducted by Reutrakul et al., the prevalence of obstructive sleep apnea syndrome in type 1 DM patients was reported as 51.9\% [22]. Sakamoto et al. reported a prevalence of $47.6 \%$ of poor sleep quality in T2DM patients [23]. In this study, the frequency of poor sleep in individuals with diabetes mellitus was $92.5 \%$. Compared to literature data, the frequency of poor sleep quality was higher in the present study. Sakamoto et al. reported that more than $90 \%$ of individuals with a diagnosis of diabetes had at least one sleep problem [23], which was similar to our findings. Literature data, as well as our findings, suggest that sleep quality is poor in patients diagnosed with diabetes mellitus.

On the other hand, the pattern is as important as the duration of sleep. Sleep latency (the time to fall asleep) was delayed in most of the participants. According to the data obtained, it can be said that the non-REM (NREM) periods of the patients are prolonged. Increased NREM duration is a sign of insomnia [24]. Therefore, it can be said that the incidence of insomnia has increased in the individuals who participated in the study. It has been reported that insomnia and similar sleep problems are common, especially in type 2 diabetic cases, and going further, insomnia has a role in the etiology of diabetes mellitus [25]. The data we obtained suggest that insomnia is common in diabetes mellitus, and it is a significant health problem. 
In the current study, the sleep quality of women was worse than men. The mean PSQI scores of both genders were 5 and above. Furthermore, $96.1 \%$ of women had poor sleep quality, while $86.1 \%$ of men had poor sleep quality. In two different studies conducted in Turkey, no relationship between sleep quality and gender had been found $[21,26]$. In general, it has been reported that the sleep quality of women is worse in the literature $[23,26,27,28]$. Literature data and our findings suggested that female gender is associated with poor sleep status.

It has been stated that the use of insulin in the treatment of diabetes mellitus will alter the blood sugar balance, especially at night, and cause a central nervous system stimulation that may impair sleep quality [29]. Rapid changes in blood sugar in patients with type 1 diabetes mellitus and hypoglycemia attacks, which are more likely to develop during nighttime sleep, lead to impairment in the duration and quality of sleep [25,30]. Although the literature supports that insulin use negatively affects sleep quality, in the present study, no difference was found concerning sleep quality between insulin-using and non-using groups. The low number of participants diagnosed with type 1 diabetes mellitus in the study population and the failure to evaluate factors such as insulin dose and duration of insulin use was thought to be the reason for the inadequacy in explaining the relationship between insulin and sleep state. We believe that new studies are needed to assess the relationship between insulin use and sleep state.

Poor sleep quality and duration have been reported to be risk factors for diabetes mellitus [31]. A meta-analysis by Zhu et al. reported that sleep disturbance, particularly impaired sleep quality, could potentially affect glycemic control in adults with type 2 diabetes [32]. In the meta-analysis conducted by Lee et al., it was emphasized that sleep quality is also important in regulating metabolic functions in patients with type 2 diabetes [33]. Lee et al.'s meta-analysis also reported that poor sleep quality is associated with increased HbA1c levels. According to the literature data, it can be said that poor sleep quality is associated with impaired metabolic parameters in patients with diabetes mellitus. In the present study, no relationship was found between sleep quality and $\mathrm{HbA1c}$, fasting and postprandial blood glucose, lipids, or blood pressure levels. It was thought that the current study data were not compatible with the literature, and the present study was insufficient to explain the relationship between metabolic parameters and sleep state.

\section{Limitations}

Our most important limitation is that the research design is cross-sectional and done in a single center. Further, proteinuria data could not be included in the analysis due to a low number of cases. The high number of questions on the scale measuring sleep caused some patients to get bored.

\section{Conclusion}

This study demonstrated that people with diabetes mellitus had poor sleep quality. Women have worse sleep quality than men. Additionally, sleep quality was worse in individuals with hypertension, hyperlipidemia and, coronary artery disease accompanying diabetes mellitus. This research is a pioneering study to raise awareness regarding the relationship between diabetes mellitus and sleep quality. With future studies, environmental or disease-related causes that may cause sleep disorders should be investigated, and these causes should be ruled out. Clinicians should also be concerned with the sleep status of patients in the follow-up of diabetes mellitus. It was thought that interventions to increase sleep quality in the follow-up of diabetes mellitus may increase the quality of life of patients with diabetes.

\section{Conflict of interest: None}

\begin{tabular}{|l|l|l|}
\hline \multicolumn{2}{|l|}{ Author Contributions } & Author Initials \\
\hline SCD & Study Conception and Design & ZA \\
\hline AD & Acquisition of Data & ZA, BB \\
\hline AID & Analysis and Interpretation of Data & ZA, BB \\
\hline DM & Drafting of Manuscript & ZA, BB \\
\hline CR & Critical Revision & ZA \\
\hline
\end{tabular}

\section{Financial support: None}

\section{References}

1. Altin Z: [Common chronic diseases with aging] (in Turkish) In: [Multidisciplinary approaches to aging from the healths sociology perspective] (in Turkish), Sahin SD (editor). Istanbul: Ekin publishing; 2020:139-56.

2. IDF Diabetes Atlas. Available at: http://www.diabetesatlas.org (Access Date: January 18, 2019).

3. Xu G, Liu B, Sun Y, Du Y, Snetselaar LG, Hu FB et al. Prevalence of diagnosed type 1 and type 2 diabetes among US adults in 2016 and 2017: population based study. BMJ 2018;362:k1497. https://doi.org/10.1136/bmj.k1497

4. Centers for Disease Control and Prevention. National diabetes statistics report 2017 . Available at: https://www.cdc.gov/diabetes/data/statistics/statistics-report.html (Access Date: January 18, 2019).

5. Turkey diabetes 2015-2020. Available at: https://extranet.who.int/ncdccs/Data/TUR D1 T\%C3\%BCrkiye\%20Diyabet\%20Program\%C4\%B1\%202015-2020.pdf (Access Date: May 31, 2020) (in Turkish)

6. Dietz WH, Robinson TN. Clinical practice. Overweight children and adolescents. N Engl J Med 2005;352:2100-9. https://doi.org/10.1056/nejmcp043052 
7. Roglic G, Unwin N, Bennett PH, Mathers C, Tuomilehto J, Nag Setal. The burden of mortality attributable to diabetes. Realistic estimates for the year 2000. Diabetes Care 2005;28(9):2130-5. https://doi.org/10.2337/diacare.28.9.2130

8. Karadag M. [Sleep disorders classification (ICSD-2)] (in Turkish). Turk Clinics Arch Lung 2007;8:88-91. Available at: http://uykubozuklugu.uludag.edu.tr/siniflama.pdf (Access Date: June 1, 2020)

9. Potter PA, Perry AG. Fundamentals of nursing, 6th edition, Elsevier mosby, St.Louispp: 1198-227. Available at: https://www.elsevier.com/books/potter-and-perrys-fundamentals-of-nursing-australian-version/crisp/978-0-7295-7862-2 (Access Date: May 31, 2020)

10. Spiegel K, Knutson K, Leproult R, Tasali E, Cauter VE. Sleep loss: a novel risk factor for insulin resistance and type 2 diabetes. J Appl Physiol 2005;99(5):2008-19. https://pubmed.ncbi.nlm.nih.gov/16227462

11. Marathe PH, Gao HX, Kapat KL. American Diabetes Association standards of medical care in diabetes. J Diabetes 2017;9(4):320-4. https://doi.org/10.1111/1753-0407.12524

12. Sharma S, Kavuru M. Sleep and metabolism: an overview. Int J Endocrinol 2010;2010:1-12. https://doi.org/10.1155/2010/270832

13. Folstein MF, Folstein S, Mc Hugh PR. "Mini mental state" A practical method for grading the cognitive state of patients for the clinician. J Psychiatr Res 1975;12(3):189-98. https://doi.org/10.1016/0022-3956(75)90026-6

14. Molloy DW, Standish TIM. A guide to the standardized mini mental state examination. Int Psychogeriatrics 1997;9:87-94. https://doi.org/10.1017/S1041610297004754

15. Gungen C, Ertan T, Eker E, Yasar R, Engin F. Reliability and validity of the standardized mini mental state examination in the diagnosis of mild dementia in Turkish population. Turk J of Psychiatry 2002;13(4):273-81. https://pubmed.ncbi.nlm.nih.gov/12794644

16. Buysse DJ, Reynolds CF, Monk TH, Berman SR, Kupfer DJ. The Pittsburgh sleep quality index: a new instrument for psychiatric practice and research. Psychiatry Research 1989;28:193-213. https://doi.org/10.1016/0165-1781(89)90047-4

17. Agargun M, Kara H, Anlar O. [Validity and reliability of Pittsburgh sleep quality index] (in Turkish). Turk J of Psychiatry 1996;7:107-15. Available at: https://ci.nii.ac.jp/naid/20001210233 (Access Date: January 18, 2019).

18. Silva M, Chaves C, Duarte J, Amaral O, Ferreira M. Sleep quality determinants among nursing students. Procedia - Soc Behav Sc 2016;217:999-1007. https://doi.org/10.1016/j.sbspro.2016.02.090

19. Tsai YW, Kann NH, Tung TH, Chao YJ, Lin CJ, Chang KC, et al. Impact of subjective sleep quality on glycemic control in type 2 diabetes mellitus. Fam Pract 2012;29(1):30-5. https://doi.org/10.1093/fampra/cmr041

20. Aysan E, Karakose S, Zaybak A, Ismailoglu EG. [Sleep quality in university students and affecting factors] (in Turkish). Dokuz Eylul Univ School Nurs Electron J 2014:7(3):193-8 Available at: https://dergipark.org.tr/tr/download/article-file/753356 (Access Date: June 20, 2020).

21. Akova I, Kocoglu G. [Relationships between sleep time, quality, physical activity level and some anthropometric measurements in adults over 20 years of age] (in Turkish). Ahi Evran Med J 2018;2(3);67-73. Available at: https://dergipark.org.tr/tr/download/article-file/612245 (Access Date: June 20, 2020).

22. Reutrakul S, Thakkinstian A, Anothaisintawee T, Chontong S, Borel AL, Perfect MM.et al. Sleep characteristics in type 1 diabetes and associations with glycemic control: systematic review and meta-analysis. Sleep Med 2016;23:26-45. https://doi.org/10.1016/j.sleep.2016.03.019

23. Sakamoto R, Yamakawa T, Takahashi K, Suzuki J, Shinoda MM, Sakamaki K, et al. Association of usual sleep quality and glycemic control in type 2 diabetes in Japanese: A cross sectional study. Sleep and Food Registry in Kanagawa (SOREKA). PloS One 2018;13(1):e0191771. https://doi.org/10.1371/journal.pone.0191771

24. Björkelund C, Carlson DB, Lapidus Letal. Sleep disturbances in midlife unrelated to 32 - year diabetes incidence. Diabetes Care 2005;28(11):2739-44. https://doi.org/10.2337/diacare.28.11.2739

25. Hayashino Y, Yamazaki S, Nakayama T, Sokejima S, Fukuhara S. Relationship between diabetes mellitus and excessive sleepiness during driving. Exp Clin Endocrinol Diabetes 2008;116(01):1-5. https://doi.org/10.1055/s-2007-984442

26. Gunes Z, Korukcu O, Ozdemir G. [Determination of sleep quality in patients with diabetes] (in Turkish). Ataturk Univ J Nurs School 2009;12(2):10-7. Available at: https://dergipark.org.tr/tr/download/article-file/29456 (Access Date: June 30, 2020).

27. Einhorn D, Stewart DA, Erman M, Gordon N, Tsimikas AP, Casal E. Prevalence apne a in a population of adults with type 2 diabetes mellitus. Endocrin Pract 2007;13(4):355-62. https://doi.org/10.4158/EP.13.4.355

28. Doi Y, Minowa M, Uchiyama M, Okawa M. Subjective sleep quality and sleep problems in the general Japanese adult population. Psychiatry Clin Neurosci 2001;55, 213-5. https://doi.org/10.1046/j.1440-1819.2001.00830.x

29. Vgontzas AN, Zoumakis E, Bixler EO, Lin HM, Follett H, Kales A, et al. Adverse effects of modest sleep restriction on sleepiness, performance, and inflammatory cytokines. J Clin Endocrinol Metab 2004;89(5):2119-26. https://doi.org/10.1210/jc.2003-031562

30. Pillar G, Schuscheim G, Weiss R, Malhotra A, McCowen KC, Shlitner A, et al. Interactions between hypoglycemia and sleep architecture in children with type 1 diabetes mellitus. J Pediatr 2003;142(2):163-8. https://doi.org/10.1067/mpd.2003.66

31. Lopes LA, Lins CM, Adeodato VG, Quental DP, Bruin PFC, Montenegro RM, et al. Restless legs syndrome and quality of sleep in type 2 diabetes. Diabetes Care 2005;28(11):2633-6. https://doi.org/10.2337/diacare.28.11.2633

32. Zhu B, Hershberger PE, Kapella MC, FritschiC. The relationship between sleep disturbance and glycaemic control in adults with type 2 diabetes: An integrative review. J Clin Nurs 2017;26(23-24):4053-64. https://doi.org/10.1111/jocn.13899

33. Lee $\mathrm{S}, \mathrm{Ng} \mathrm{KY}$, Chin WK. The impact of sleep amount and sleep quality on glycemic control in type 2 diabetes: A systematic review and metaanalysis. Sleep Med Rev 2017;31: 91-101. https://doi.org/10.1016/j.smrv.2016.02.001 